\title{
Efficacy of Phytoseiulus persimilis and Amblyseius swirskii for integrated pest management for greenhouse cucumbers under Mediterranean environmental conditions
}

\author{
André Abou-Haidar ${ }^{1}$, Patil Tawidian ${ }^{1 \dagger}$, Hana Sobh $^{1}$, Margaret Skinner ${ }^{2}$, Bruce Parker $^{2}$, and \\ Yusuf Abou-Jawdah ${ }^{1 \star(1)}$ \\ ${ }^{1}$ Faculty of Agricultural and Food Sciences, American University of Beirut, PO Box 11-0236, Riad El-Solh, Beirut, Lebanon \\ and ${ }^{2}$ Entomology Research Laboratory, University of Vermont, 661 Spear Street, Burlington, Vermont, 05405-0105, \\ United States of America \\ ${ }^{*}$ Corresponding author. Email: abujawyf@aub.edu.lb3
}

(Received 22 July 2020; accepted 23 November 2020; first published online 26 May 2021)

\begin{abstract}
The greenhouse cucumber pests, Bemisia tabaci (Hemiptera: Aleyrodidae), Frankliniella occidentalis (Thysanoptera: Thripidae), and Tetranychus urticae (Acari: Tetranychidae), are major threats to the production of greenhouse cucumbers (Cucurbitaceae) in Lebanon. The development of insecticide resistance by these pests has prompted the use of alternative and sustainable pest management strategies. In this study, we used integrated pest management strategies, including the release of the biological control agents, Amblyseius swirskii Athias-Henriot (Mesostigmata: Phytoseiidae) and Phytoseiulus persimilis Athias-Henriot (Mesostigmata: Phytoseiidae), to control whitefly, thrips, and two-spotted spider mite populations on greenhouse cucumber plants in two commercial production sites (sites A and B). We also compared the efficacy of pest population suppression using the integrated pest management strategy with that of chemical pest control. Our results show that biological control effectively maintains the cucumber pest populations below the economic threshold when coupled with additional integrated pest management measures. In addition, we show that biological control agents were equally or more effective in pest population suppression compared to eight and 12 insecticidal and acaricidal sprays performed in the control greenhouses at sites A and B, respectively. Altogether, our results show the efficacy of adopting integrated pest management and biological control for pest population suppression in greenhouse cucumber production under Mediterranean environmental conditions.
\end{abstract}

\section{Introduction}

Integrated pest management is a technique widely used to reduce pest populations by integrating diverse strategies, including biological control agents (van Lenteren and Woets 1988; Peshin and Dhawan 2009; Hoy 2012; Naranjo et al. 2015). Biological control helps to prevent the development of insecticide resistance and minimises the impact of insecticides on the environment and human health (van Lenteren and Woets 1988; Barzman et al. 2015). The

${ }^{\dagger}$ Present address: Division of Biology, College of Arts and Sciences, Kansas State University, Manhattan, Kansas, 66506, United States of America.

Subject editor: Roselyne Labbé

(c) The Author(s), 2021. Published by Cambridge University Press on behalf of the Entomological Society of Canada. This is an Open Access article, distributed under the terms of the Creative Commons Attribution-NonCommercial-NoDerivatives licence (http://creativecommons. org/licenses/by-nc-nd/4.0/), which permits non-commercial re-use, distribution, and reproduction in any medium, provided the original work is unaltered and is properly cited. The written permission of Cambridge University Press must be obtained for commercial re-use or in order to create a derivative work 
numerous benefits of using biological control agents over chemical pest control have driven interest in their application in diverse pest control strategies.

Although the greenhouse environment favours optimal cucumber (Cucurbitaceae) production, it also favours the rapid development of insect and mite populations (Messelink et al. 2020). Among cucumber arthropod pests, whiteflies, Bemisia tabaci Gennadius (Hemiptera: Aleyrodidae), thrips, Frankliniella occidentalis Pergande (Thysanoptera: Thripidae), and two-spotted spider mites, Tetranychus urticae Koch (Acari: Tetranychidae), cause significant damage to the cucumber host directly through feeding on plant sap and indirectly through transmitting viral diseases (McClanahan 1970; Rosenheim et al. 1990; Gaum et al. 1994; Hao et al. 2002; Park and Lee 2002, 2005; Jones 2003). The primary strategy to control these cucumber pests has been the application of insecticides and acaricides. However, the over-reliance on and misuse of these chemical pest control agents have promoted insecticide and acaricide resistance (Gorman et al. 2002; Van Leeuwen et al. 2010; Gao et al. 2012; Lebedev et al. 2013; Cloyd 2016; Horowitz et al. 2020). Alternative pest control strategies are required to maintain the whitefly, thrips, and two-spotted spider mite populations below damaging levels on cucumber plants.

Amblyseius swirskii Athias-Henriot (Mesostigmata: Phytoseiidae), a generalist predatory mite originating from the east Mediterranean coast (Athias-Henriot 1962; Calvo et al. 2015; Demite et al. 2015), is widely used in biological control strategies on numerous ornamental and vegetable crops, including solanaceous and cucurbit crops (Calvo et al. 2015). Amblyseius swirskii efficiently controls diverse arthropod pest populations, including whiteflies, thrips, and to a lesser extent, several mite species (Cock et al. 2010; van Maanen et al. 2010; van Lenteren 2012; Calvo et al. 2015). Laboratory and greenhouse studies report the effective suppression of whitefly and thrips populations either separately or during simultaneous infestation on cucumber leaves by adult $A$. swirskii mites (Nomikou et al. 2001, 2002; Messelink et al. 2005, 2006; Calvo et al. 2011). However, knowledge on the efficacy of whitefly and thrips population control by A. swirskii under commercial greenhouse production conditions in Lebanon remains lacking.

Although A. swirskii adults prey on two-spotted red spider mite eggs and nymphs, their main host preference remains whiteflies and thrips (Xu and Enkegaard 2010; Calvo et al. 2015). This preference necessitates the use of an additional natural enemy, the predatory mite Phytoseiulus persimilis Athias-Henriot (Mesostigmata: Phytoseiidae). Phytoseiulus persimilis is a specialised predator of Tetranychus sp., including the two-spotted spider mites (McMurtry et al. 2013). Since the 1960s, P. persimilis has been used widely for the efficient control of two-spotted spider mite populations in cucumber plants under greenhouse and laboratory conditions (Masoud 2007; van Houten et al. 2007b; Gillian 2008; Gontijo et al. 2010; McMurtry et al. 2013; Fathipour et al. 2017). This predatory mite species is characterised by a high population density when fed on T. urticae eggs and nymphs (Escudero and Ferragut 2005; Moghadasi et al. 2016). Furthermore, studies have determined P. persimilis to tolerate increasing temperatures and humidity levels, rendering it suitable for greenhouse environments (Mori and Chant 1966; Stenseth 1979; Skirvin and Fenlon 2003). Therefore, the ability of $P$. persimilis to reproduce while feeding on different $T$. uritcae life stages and to tolerate increased temperatures and humidity makes it a desirable candidate for two-spotted spider mite management on cucumber plants under greenhouse conditions. However, the simultaneous introduction of different predatory mites can lead to a negative outcome due to intraguild predation, whereby competition for the same food can lead to cannibalism among species (Polis 1981; Polis et al. 1989). Few studies have shown intraguild predation by $A$. swirskii mites on $P$. persimilis nymphs, larvae, and eggs in the absence of an alternative and preferred food source (Haghani et al. 2015; Maleknia et al. 2016). However, a study conducted on sweet-pepper plants (Solanaceae) showed successful control of T. urticae by P. persimilis in the presence of A. swirskii mites (van Houten et al. 2007a). This 
suggests that when preferred prey are available, the introduction of two predatory mite species to control greenhouse pests may be possible.

The overall objective of this study was to evaluate the efficacy of integrated pest management strategies that mainly rely on the release of $A$. swirskii and P. persimilis and are complemented, when needed, by the application of pesticides that are relatively safe to predatory mites for the control of whiteflies, thrips, and two-spotted spider mites on greenhouse cucumbers, as compared to the efficacy of routine chemical pest control strategies that are commonly followed by commercial cucumber growers in Lebanon. Pesticide applications in the integrated pest management greenhouses were determined by using published economic thresholds for each pest and the expected arrival of predatory mites. Economic threshold is defined as the insect population density at which control measures should be taken to prevent the pest population from reaching economically damaging levels (Higley and Pedigo 1996; Costa et al. 2019). The economic threshold varies for each pest, being 4.6 adult whiteflies per leaf (Shen et al. 2005), 1.3 adult thrips per leaf (Steiner 1990), and 3-5 adult thrips per flower (Shipp et al. 2000). Although the economic threshold of two-spotted spider mites on cucumber leaves has not yet been reported, a population of two two-spotted spider mite adults per leaf at the seventh- or eighth-leaf stage was shown to cause a $23.8 \%$ loss in cucumber yield (Atanassov 1997). This value was used as an indicator of acaricide application in the integrated pest management greenhouses.

\section{Materials and methods}

\section{Greenhouses}

Experiments were conducted at site A in Tamich, Mount Lebanon, Lebanon at an altitude of $250 \mathrm{~m}$, and at site B in Zahrani, Southern Lebanon, at $5 \mathrm{~m}$. At each site, two polyethylene plasticcovered greenhouses equipped with 50 -mesh insect-proof nets were randomly selected. The area of each greenhouse at site A was $414 \mathrm{~m}^{2}$, whereas that at site B was $320 \mathrm{~m}^{2}$. This study was conducted in greenhouses provided by commercial vegetable growers, and only two greenhouses from each location were provided for our experiments. At each location, one greenhouse served as a control, where conventional pest management techniques were followed; in the other greenhouse, integrated pest management practices were implemented, with multiple natural enemy releases. Access to the greenhouses was granted through double doors. Daily temperature $\left({ }^{\circ} \mathrm{C}\right)$ and relative humidity (\%) were recorded at 15 -minute intervals in the integrated pest management greenhouses at both sites, using HOBO data loggers (Ebro, New York, New York, United States of America).

\section{Plants and cultural practices}

In the integrated pest management greenhouses, plant debris from the previous growing season was removed and burned to minimise disease incidence. Additionally, weeds surrounding and growing inside the greenhouses were removed by hand. In the control greenhouses, one week before transplanting, the polyethylene plastic covers were sprayed with the insecticide Morgan (Lapisa, Mexico; $48 \%$ chlorpyrifos ethyl w/v) at the company's recommended application rate of $2.5 \mathrm{~mL} / \mathrm{L}$ to eliminate insects in the greenhouses.

Seedlings of cucumber, Cucumis sativus Linnaeus, varieties "New sun" and "Mira" were transplanted at a rate of three seedlings per square metre in the greenhouses at sites A and B on 3 November and 19 October 2016, respectively. The integrated pest management and control greenhouses at sites A and B contained 1240 and 960 cucumber seedlings, respectively, transplanted in 10 rows. The farmer at site A used a hydroponic farming method with hydrogen peroxide-disinfected coco-peat as a growth substrate, whereas the farmer at site $\mathrm{B}$ adopted a conventional farming method using soil as the growing medium. One week 
before transplanting the seedlings, three seedlings per pot (diameter: $17 \mathrm{~cm}$; height: $13 \mathrm{~cm}$ ) of flowering marigolds, Tagetes patula (Asteraceae) (Marigold French Hero, Yellow; Ball Seed, West Chicago, Illinois, United States of America), were introduced in the integrated pest management greenhouses at a rate of 1 pot $/ 32 \mathrm{~m}^{2}$ to attract existing and newly emerging thrips populations (Kasina et al. 2006). Before the cucumber seedlings were transplanted, the pots of marigolds were covered with plastic bags and discarded and new uninfested pots of marigolds were introduced. In addition, yellow sticky traps were installed in the integrated pest management greenhouses at a rate of $1 \mathrm{card} / 16 \mathrm{~m}^{2}$ to monitor existing whiteflies and thrips. To scout the sticky traps, the integrated pest management greenhouses were divided into quadrants. Five traps were removed - one from each greenhouse quadrant and one from the middle - they were scouted and then replaced by new traps every week.

\section{Predatory mites}

Upon consultation with technical advisors from BioBest (Westerlo, Belgium), the predatory mites A. swirskii and $P$. persimilis were selected as suitable predatory mites for our experimental conditions. The predatory mites and Nutrimite, an alternative food source for A. swirskii that consists of the pollen of the narrow-leaved cattail, Typha angustifolia (Typhaceae), were obtained from a commercial supplier (BioBest). Amblyseius swirskii was provided in two formats: in cardboard bottles, each of which contained 25000 individuals (nymphs and young adults); and in 500 slow-release sachets, each of which contained 250 nymphs and young adults (totalling 125000 individuals), according to the experimental requirements. Both formats were mixed with bran and factitious prey, Tyrophagus putrescentiae (Sarcoptiformes: Acaridae), as a food source during transport in cold containers. Phytoseiulus persimilis were obtained in plastic bottles, each containing 2000 individuals (young adults), with vermiculite as a carrier (Table 1). All predatory mites were kept at room temperature for 30 minutes before release, per manufacturer's recommendation. Amblyseius swirskii mites received in slow-release sachets were hung on the stems of randomly selected cucumber plants, and those received in bottles were sprinkled on randomly selected cucumber leaves. At the beginning of the growing season, the seedlings were dusted with T. angustifolia pollen as an alternative food source for A. swirskii. Phytoseiulus persimilis mites were sprinkled in hot spots - that is, on cucumber leaves infested by two-spotted spider mites. Predatory mite releases and pollen sprays were not performed in the control greenhouses. Throughout the growing season, infestation of the cucumber plants by B. tabaci, F. occidentalis, and T. urticae occurred naturally, without the pests being introduced by artificial means.

\section{Experimental design and sampling}

The effect of A. swirskii and P. persimilis on whiteflies, thrips, and two-spotted spider mites was assessed through four predatory mite releases in the integrated pest management greenhouse at site A and through five predatory mite releases in the integrated pest management greenhouse at site B. Cucumber plants at both sites were scouted weekly for predatory mite and pest populations. Scouting was performed on 50 randomly selected cucumber plants (five cucumber plants per row). Three leaves and three flowers from the top, middle, and lower parts of each selected cucumber plant were randomly chosen and scouted, totalling 150 leaves and 150 flowers per greenhouse per week for 20 weeks in the control greenhouses and for 25 and 22 weeks in the integrated pest management greenhouses at sites A and B, respectively. Additionally, marigold flowers were scouted weekly for infestation by adult thrips. Highly infested marigold plants and cucumber leaves were removed from the integrated pest management greenhouses and burned, with new, uninfested marigolds then introduced. 
Table 1. Predatory mite (Amblyseius swirskii and Phytoseiulus persimilis) release dates and rates in the integrated pest management greenhouses at sites A and B.

\begin{tabular}{|c|c|c|c|c|c|}
\hline \multicolumn{3}{|c|}{ Site $A$} & \multicolumn{3}{|c|}{ Site B } \\
\hline Date (week) & Predatory mites & $\begin{array}{l}\text { Rate (mites or } \\
\text { pollen } / \mathrm{m}^{2} \text { ) }\end{array}$ & Date (week) & Predatory mites & $\begin{array}{l}\text { Rate (mites or } \\
\text { pollen } / \mathrm{m}^{2} \text { ) }\end{array}$ \\
\hline \multirow[t]{2}{*}{22 November 2016 (3) } & A. swirskii system bottle (25 000 mites) & 60 & \multirow[t]{2}{*}{4 November 2016 (2) } & A. swirskii system bottle (25000 mites) & 78 \\
\hline & Nutrimite & $0.15 \mathrm{~g}$ & & Nutrimite & $0.15 \mathrm{~g}$ \\
\hline \multirow[t]{2}{*}{14 December 2016 (6) } & A. swirskii breeding system (100 sachets) & 60 & \multirow[t]{2}{*}{22 November 2016 (5) } & \multirow[t]{2}{*}{ A. swirskii breeding system (100 sachets) } & \multirow[t]{2}{*}{78} \\
\hline & P. persimilis 2 bottles (2000 mite/bottle) & 10 & & & \\
\hline \multirow[t]{2}{*}{23 February 2017 (17) } & A. swirskii breeding system (100 sachets) & 60 & \multirow[t]{2}{*}{14 December 2016 (8) } & A. swirskii breeding system (100 sachets) & 78 \\
\hline & P. persimilis 2 bottles (2000 mites/bottle) & 10 & & P. persimilis 2 bottles (2000 mite/bottle) & 12.5 \\
\hline \multirow[t]{2}{*}{31 March 2017 (22) } & A. swirskii system bottle ( $1 / 2$ bottle) ( 25000 mites) & 60 & \multirow[t]{2}{*}{22 February 2017 (17) } & A. swirskii breeding system (100 sachets) & 78 \\
\hline & P. persimilis 6 bottles (2000 mites/bottle) & 29 & & P. persimilis 2 bottles (2000 mites/bottle) & 12.5 \\
\hline & & & 31 March 2017 (21) & P. persimilis 2 bottles ( 2000 mites/bottle) & 31 March 2017 \\
\hline
\end{tabular}


The number and rate of releases depended on the environmental conditions and pest infestation level. See Table 1 for details of the predatory mite release rates and dates. Based on pest population-monitoring results, the first releases of $A$. swirskii mites at sites A and B were on weeks 3 and 2 of the experimental period, respectively. However, releases of $P$. persimilis mites were delayed until weeks 6 and 8 at sites A and B, respectively, due to the absence of two-spotted spider mites early in the growing season.

\section{Pesticide applications}

In the control greenhouses, the farmers maintained their routine insect and disease management strategies. However, in the integrated pest management greenhouses, data sheets published by Koppert (Berkel en Rodenrijs, The Netherlands) and BioBest were used to select pesticides with minimal side effects on the predatory mites. See Supplementary material, Tables S1 and S2 for details of the applied pesticides, including rates and dates of application, active ingredients, and target pests, for both greenhouses at sites A and B.

\section{Statistical analysis}

The weekly insect scouting data from 150 leaves and 150 flowers were assessed for non-normality using the Shapiro-Wilk normality test. The effects of the predatory mites on whitefly, thrips, and spider mite populations were compared to the pests' populations in the control greenhouses on the mean weekly scouting data (weeks 1-20) of 150 leaves and flowers using the nonparametric Mann-Whitney $U$ test and parametric Welch's $t$-test. Spearman's Rho was used to describe the correlation between the mean populations of $A$. swirskii, whitefly, and thrips, $P$. persimilis and two-spotted spider mites, and $P$. persimilis and A. swirskii from 150 leaves per week until the experiment was ended in the integrated pest management greenhouses (at week 25 at site A and at week 22 at site B). The strength of the relationship between predatory mites and the pest populations was determined using the correlation coefficient $r$ and was described as no correlation (0.0), weak (0.1-0.3), moderate (0.4-0.6), and strong (0.7-1.0; Akoglu et al. 2018). In addition, the mean whitefly adult population from five yellow sticky traps per week was used to assess possible adult migration into the integrated pest management greenhouses from the surrounding environment. All the statistical analyses were performed using GraphPad prism, version 8.4.3.

\section{Results}

\section{Ambient conditions}

In site A, the mean weekly temperature varied from $14.2^{\circ} \mathrm{C}$ in week 3 to $18.3^{\circ} \mathrm{C}$ in week 20 (minimum and maximum mean temperatures being $5.8^{\circ} \mathrm{C}$ and $26.2^{\circ} \mathrm{C}$, respectively). The average relative humidity ranged from 45 to $80 \%$ (Fig. 1A). In site B, the mean weekly temperature varied from $24.3{ }^{\circ} \mathrm{C}$ in week 3 to $22.6{ }^{\circ} \mathrm{C}$ in week 20 (minimum and maximum mean temperatures being $12.18{ }^{\circ} \mathrm{C}$ and $24.3{ }^{\circ} \mathrm{C}$, respectively), and the average relative humidity ranged from 60 to 80\% (Fig. 1B).

\section{Whitefly management}

Site A. In the site A control greenhouse, five insecticide applications maintained the whitefly nymph and adult populations below the economic threshold throughout the growing period (Fig. 2A). In the integrated pest management greenhouse, the whitefly adult population remained below the economic threshold of 4.6 whitefly adults per leaf (Shen et al. 2005) during the 23-week growing period. Similarly, without application of insecticides targeting 

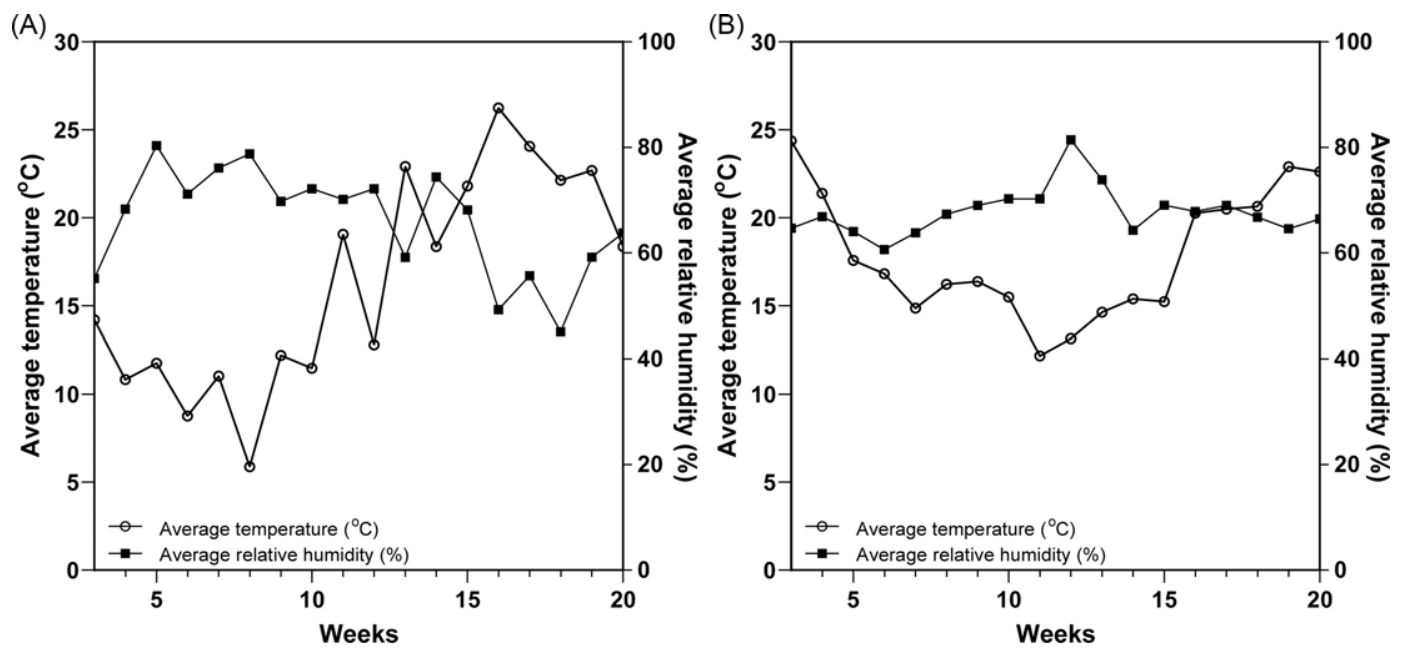

Fig. 1. Mean temperature $\left({ }^{\circ} \mathrm{C}\right)$ and relative humidity (\%) under the integrated pest management greenhouse conditions per week from early winter 2016 until spring 2017. A, Mean temperature and relative humidity in the integrated pest-managed greenhouse at site A; B, mean temperature and relative humidity in the integrated pest-managed greenhouse at site $B$.

whiteflies, whitefly nymph numbers remained below 1.5 insects per leaf during the entire growing period (Fig. 2B). In the last two weeks of the experiment, a peak of eight whitefly adults per leaf was recorded. In addition, the mean number of adult whiteflies recorded on sticky cards $(9.4 \pm 1.2)$ was more than 30 times higher than the mean number of adult whiteflies recorded on cucumber leaves $(0.320 \pm 0.076)$, suggesting whitefly adult migration from the surrounding environment. A significant moderate positive correlation was recorded between the whitefly adult and $A$. swirskii populations $(r=0.452 ; P=0.023$; Table 3$)$, whereas a nonsignificant weak positive correlation was recorded between whitefly nymphs and A. swirskii populations $(r=0.167, P=0.424)$. The mean numbers of whitefly nymphs and adults on cucumber leaves in the integrated pest management greenhouse did not significantly differ compared to the nymph and adult populations in the control greenhouse ( $U=174.5, P=0.268 ; U=182.5, P=0.644$; Table 2 ).

Site B. At site B, the whitefly nymph and adult populations were maintained below the economic threshold in both the integrated pest management and control greenhouses. With 12 whitefly-targeting insecticide applications in the control greenhouse, the peak was two whitefly adults per leaf (Fig. 2C). In the integrated pest management greenhouse, where no whitefly-targeting insecticide had been applied, the peak of whitefly adults on cucumber leaves was 2.7 adults (Fig. 2D). Similar to site A, the mean number of adult whiteflies recorded on sticky cards $(8.2 \pm 0.840)$ was more than 30 times higher than the mean number of the adult flies recorded on cucumber leaves $(0.713 \pm 0.178)$. A significant moderate positive correlation was recorded between the whitefly adult and A. swirskii populations $(r=0.585$, $P=0.0042$; Table 3). However, the moderate positive correlation between the nymph population with that of the predatory mite was not significant $(r=0.371 ; P=0.089$; Table 3$)$. The mean number of whitefly nymphs, although below the economic threshold, was significantly higher in the integrated pest management greenhouse $(U=131, P=0.0436)$. However, the mean number of whitefly adults did not significantly differ between the integrated pest management and control greenhouses $(U=159.5, P=0.279$; Table 2$)$.

\section{Thrips management}

Site A. At site A, in the control greenhouse, the application of five thrips-targeting insecticidal sprays contributed to the decline of the thrips population on cucumber leaves and flowers to below 
$(\mathrm{A})_{10}$

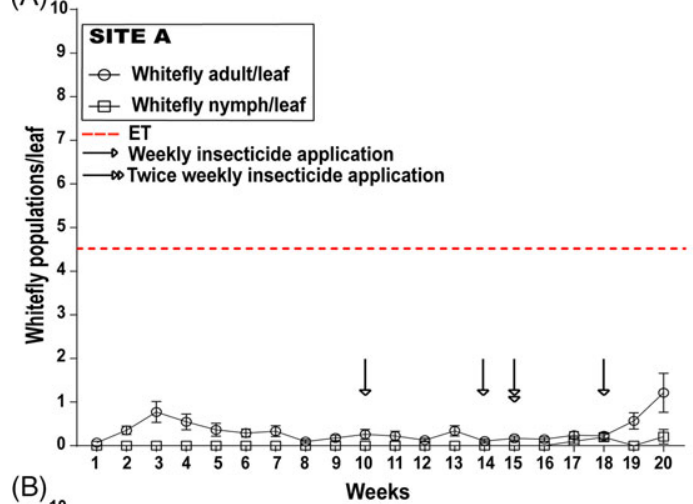

(B)

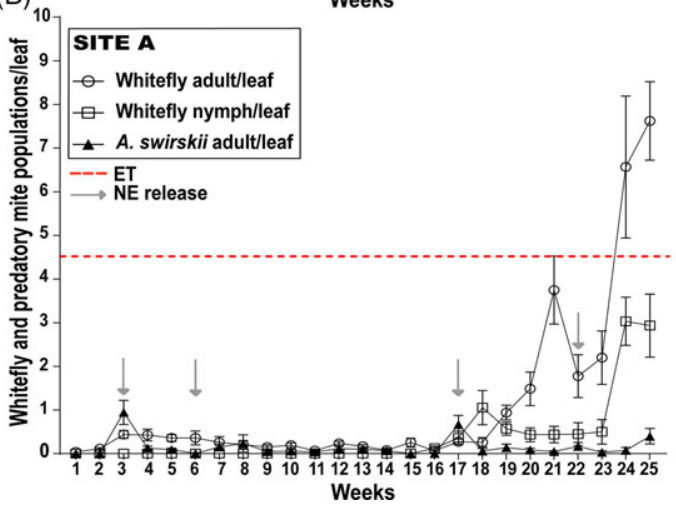

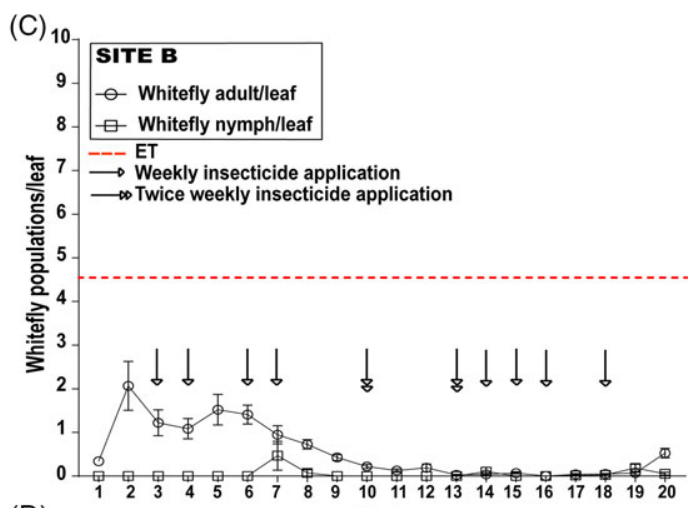

(D) 10

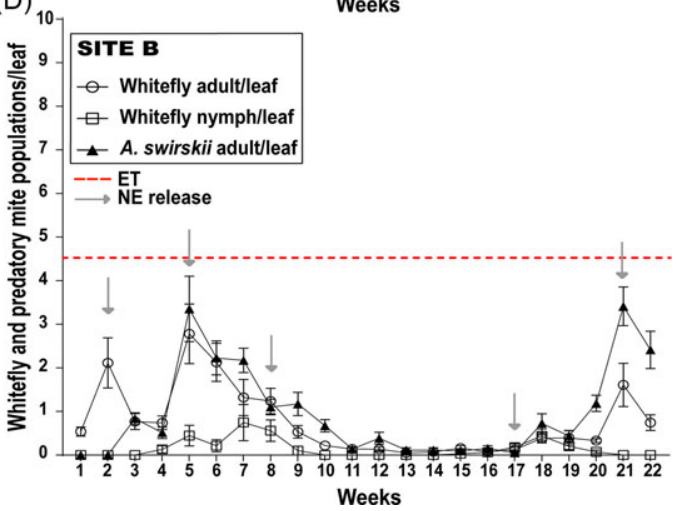

Fig. 2. The average number of whitefly nymphs and adults and Amblyseius swirskii adults on cucumber leaves in the integrated pest management and control greenhouses at sites A and B. A, Whitefly nymph and adult populations in the control greenhouse at site A; B, whitefly nymph and adult and $A$. swirskii populations per cucumber leaf in the integrated pest-managed greenhouse at site A; $\mathbf{C}$, whitefly nymph and adult populations in the control greenhouse at site B; $\mathbf{D}$, whitefly nymph and adult and $A$. swirskii adult populations on per cucumber leaf in the integrated pestmanaged greenhouse at site B. The error bars indicate the standard error of mean. Natural enemy releases (NE; grey arrows), weekly whitefly-targeting insecticide sprays (black arrows), and economic threshold (ET; dashed red line).

the economic threshold of 1.3 thrips adults per leaf (Steiner 1990) and 3-5 thrips per flower (Shipp et al. 2000). The thrips population was maintained below the economic threshold for up to 10 weeks, followed by an increase in thrips numbers to a peak of three thrips adults per leaf (Fig. 3A). In the integrated pest management greenhouse, four A. swirskii releases maintained the thrips population below the economic threshold throughout the growing period (Fig. 3B). Peaks in A. swirskii numbers were recorded a week following each release. A weak nonsignificant positive correlation occurred between the thrips and A. swirskii populations $(r=0.209 ; P=0.316$; Table 3$)$. Although the thrips population remained below the economic threshold during most of the growing season, the mean number of thrips recorded per cucumber leaf and flower was significantly higher in the control greenhouse compared to the corresponding mean number recorded in the integrated pest management greenhouse ( $U=61, P<0.0001 ; U=103.5, P=0.007$; Table 2).

Site B. In the site B control greenhouse, 12 insecticidal sprays targeting thrips kept the thrips population on cucumber leaves and flowers below the economic threshold throughout the growing season (Fig. 3C). In the integrated pest management greenhouse, a thrips count of 1.5 thrips per leaf was recorded starting week 11, but the population on cucumber flowers remained below the economic threshold. As temperatures increased after week 11, the thrips 

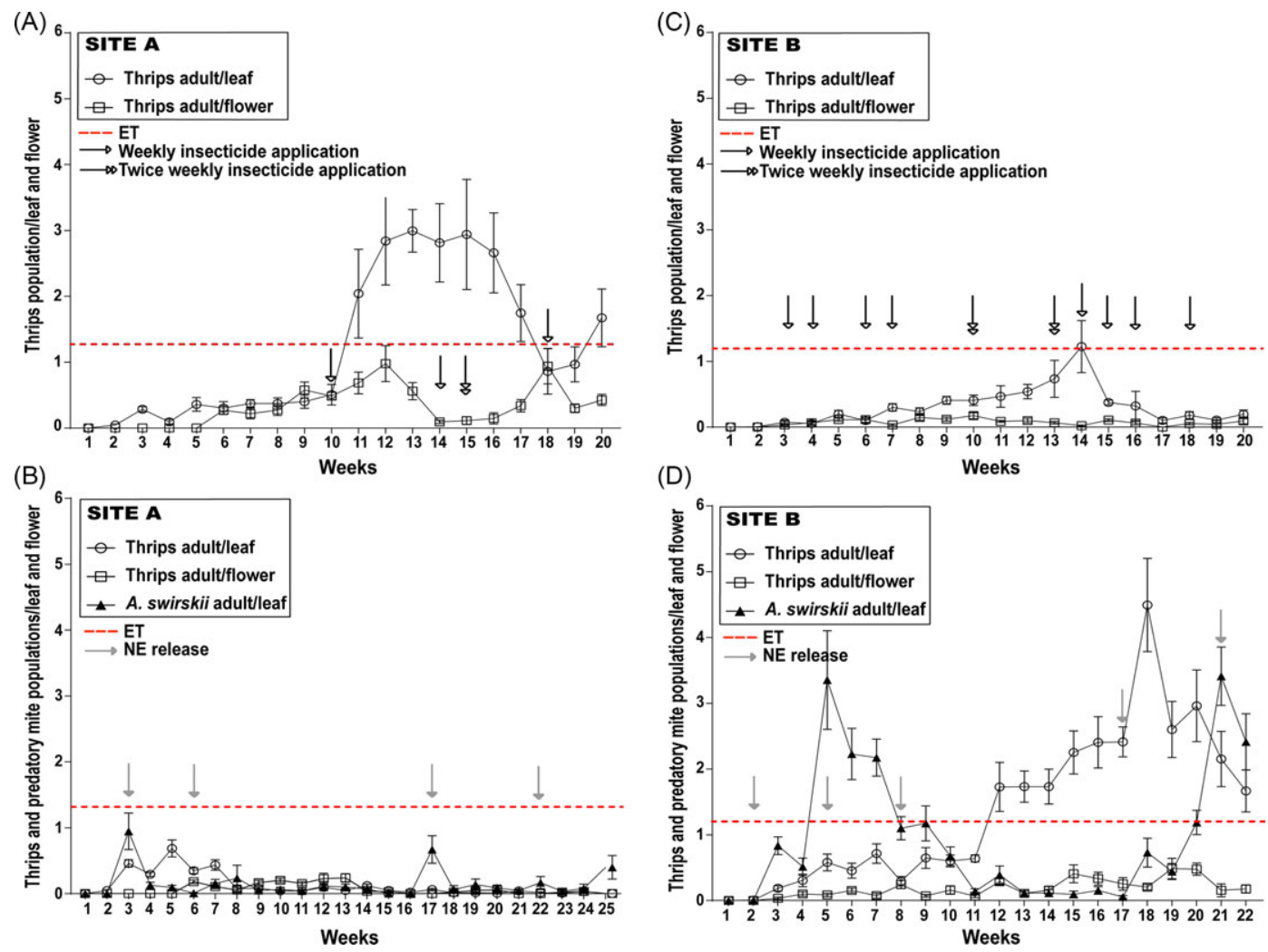

Fig. 3. The average number of adult thrips and Amblyseius swirskii on cucumber leaves and flowers in the integrated pest management and control greenhouses at sites A and B. A, Thrips population per cucumber leaf and flower in the control greenhouse at site $\mathbf{A}$; $\mathbf{B}$, thrips and $A$. swirskii populations per cucumber leaf and thrips per cucumber flower in the integrated pest-managed greenhouse at site A; C, thrips population per cucumber leaf and flower in the control greenhouse at site B; D, thrips and A. swirskii populations per cucumber leaf and thrips per cucumber flower in the integrated pest-managed greenhouse at site B. The error bars indicate the standard error of mean. Natural enemy releases (NE; grey arrows), weekly thrips-targeting insecticide sprays (black arrows), and economic threshold (ET; dashed red line).

population peaked beyond the economic threshold, reaching a maximum of 4.5 thrips adults per leaf. A new introduction of A. swirskii on week 17 led to the gradual decline in the thrips population. By the end of the growing season, the thrips population on cucumber leaves was declining towards the economic threshold, whereas the A. swirskii population had increased to 3.5 predatory mites per leaf (Fig. 3D). There was no evidence of a correlation between the populations of thrips on cucumber leaves and flowers and that of A. swirskii $(r=0.019$; $P=0.934$, and $r=0.031 ; P=0.890$; Table 3 ). The mean number of thrips on cucumber leaves and flowers was significantly higher in the integrated pest management greenhouse than in the control greenhouse $(U=81, P=0.0009 ; t=3.235, P=0.0036$, and Welch's $t=3.23$; $P=0.0036$; Table 2).

\section{Two-spotted spider mite management}

Site A. In the integrated pest management and control greenhouses at site A, two-spotted spider mite numbers were below two mites per leaf until weeks 15 and 16 . In the control greenhouse, despite seven acaricide sprays, the two-spotted spider mite population increased 
Table 2. The mean number of insects and spider mites \pm standard error of mean (SEM) in the integrated pest management (IPM) and control greenhouses at both study sites. The nonparametric Mann-Whitney $U$ test was used to test for significant difference between the treatment groups.

\begin{tabular}{|c|c|c|c|c|c|c|}
\hline Study site & $\begin{array}{l}\text { Management } \\
\text { programme }\end{array}$ & $\begin{array}{c}\text { Mean thrips/leaf } \\
\pm \mathrm{SEM}^{*}\end{array}$ & $\begin{array}{c}\text { Mean thrips/flower } \\
\pm \text { SEM }\end{array}$ & 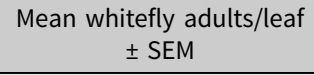 & $\begin{array}{c}\text { Mean whitefly nymphs/leaf } \\
\pm \text { SEM }\end{array}$ & $\begin{array}{c}\text { Mean MITES/LEAF } \\
\pm \text { SEM }\end{array}$ \\
\hline \multirow[t]{4}{*}{ Site A } & IPM & $0.121 \pm 0.036$ & $0.063 \pm 0.016$ & $0.320 \pm 0.076$ & $0.127 \pm 0.062$ & $1.478 \pm 0.532$ \\
\hline & Control & $1.214 \pm 0.251$ & $0.321 \pm 0.068$ & $0.331 \pm 0.061$ & $0.025 \pm 0.014$ & $3.348 \pm 1.290$ \\
\hline & Mann-Whitney U & 65.5 & 121 & 182.5 & 174.5 & 175.5 \\
\hline & $P$-value & $<0.0001^{\star}$ & $0.0022^{\star}$ & 0.644 & 0.268 & 0.516 \\
\hline \multirow[t]{5}{*}{ Site B } & IPM & $1.34 \pm 0.272$ & $0.185 \pm 0.033$ & $0.713 \pm 0.178$ & $0.159 \pm 0.049$ & $0.706 \pm 0.183$ \\
\hline & Control & $0.301 \pm 0.065$ & $0.071 \pm 0.011$ & $0.556 \pm 0.138$ & $0.046 \pm 0.024$ & $0.366 \pm 0.104$ \\
\hline & Mann-Whitney U & 81 & - & 159.5 & 131 & 161 \\
\hline & Welch's $t$-test & - & 3.235 & - & - & - \\
\hline & $P$-value & $<0.0009^{\star}$ & $0.0036^{\star}$ & 0.2796 & $0.0436^{\star}$ & 0.2951 \\
\hline
\end{tabular}

*Statistical significance at $P<0.05$. 
Table 3. Spearman correlation test between the cucumber pests and predatory mites (Amblyseius swirskii and Phytoseiulus persimilis) in the integrated pest management greenhouses at both study sites.

\begin{tabular}{|c|c|c|c|c|c|c|c|c|}
\hline \multirow[b]{3}{*}{ Insects/spider mite } & \multicolumn{4}{|c|}{ Site A } & \multicolumn{4}{|c|}{ Site B } \\
\hline & \multicolumn{2}{|c|}{ A. swirskii } & \multicolumn{2}{|c|}{ P. persimilis } & \multicolumn{2}{|c|}{ A. swirskii } & \multicolumn{2}{|c|}{ P. persimilis } \\
\hline & $r$ & $P$ & $r$ & $P$ & $r$ & $P$ & $r$ & $P$ \\
\hline Whitefly adults & 0.452 & $0.023^{\star}$ & & & 0.585 & $0.004^{*}$ & & \\
\hline Whitefly nymphs & 0.167 & 0.424 & & & 0.371 & 0.089 & & \\
\hline Thrips adults/leaf & 0.209 & 0.316 & & & 0.019 & 0.934 & & \\
\hline Thrips adults/flower & -0.056 & 0.789 & & & 0.031 & 0.890 & & \\
\hline Two-spotted spider mites & & & 0.649 & $0.0004^{\star}$ & & & 0.788 & $<0.0001^{\star}$ \\
\hline \multicolumn{9}{|l|}{ Predatory mite } \\
\hline P. persimilis & 0.391 & 0.585 & & & 0.010 & 0.949 & & \\
\hline
\end{tabular}

*Statistical significance at $P<0.05$.
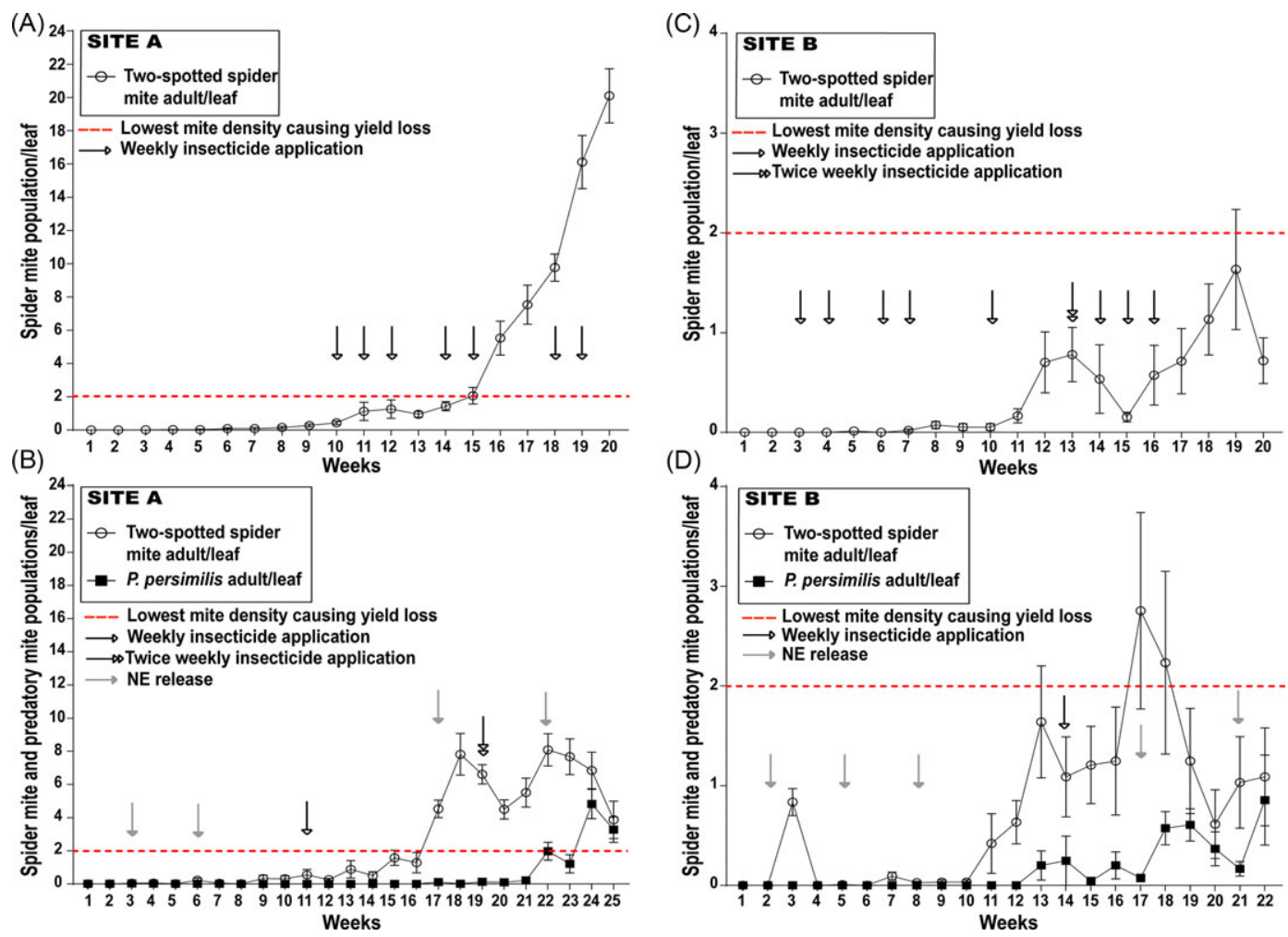

Fig. 4. The average number of two-spotted spider mite adults and Phytoseiulus persimilis adults on cucumber leaves in the integrated pest management and control greenhouses at sites A and B. A, Two-spotted spider mite adult population per cucumber leaf in the control greenhouse at site A; B, two-spotted spider mite adult and $P$. persimilis adult populations per cucumber leaf in the integrated pest-managed greenhouse at site $\mathbf{A} ; \mathbf{C}$, two-spotted spider mite adult population per cucumber leaf in the control greenhouse at site $\mathbf{B}$; $\mathbf{D}$, two-spotted spider mite adult and $P$. persimilis adult populations per cucumber leaf in the integrated pest-managed greenhouse at site B. The error bars indicate the standard error of mean. Natural enemy releases (NE; grey arrows), weekly two-spotted spider mite targeting acaricide sprays (black arrows), and spider mite population density at which $23.8 \%$ cucumber yield loss is recorded (dashed red line). 
steadily, reaching a peak of 20 two-spotted spider mites per leaf. Thus, the farmer was forced to stop production in the control greenhouse at 20 weeks post-transplanting (Fig. 4A). In the integrated pest management greenhouse, three $P$. persimilis releases and three acaricide sprays with minimal side effects on $P$. persimilis contributed to the reduction of the two-spotted spider mite population to four two-spotted spider mites per leaf at the end of the growing season (Fig. 4B). A significant moderate positive correlation was recorded between the two-spotted spider mite and the $P$. persimilis populations, with a peak of four $P$. persimilis mites per leaf $(r=0.649, P=0.0004$; Table 3$)$. The mean numbers of two-spotted spider mites in both the integrated pest management and control greenhouses did not significantly differ $(U=175.5, P=0.516$; Table 2$)$. In addition, a nonsignificant weak positive correlation was recorded between the $P$. persimilis and A. swirskii populations in the integrated pest management greenhouse ( $r=0.391, P=0.585$; Table 3$)$.

Site B. In the site B control greenhouse, 10 acaricide sprays maintained the two-spotted spider mite population below two spider mites per leaf throughout the growing period (Fig. 4C; Table 3). In the integrated pest management greenhouse, three predatory mite releases and one acaricide application with minimal side effects on $P$. persimilis maintained the two-spotted spider mite population below two spider mites per leaf throughout the growing period (Fig. 4D). A significant strong positive correlation was recorded between the two-spotted spider mite and the $P$. persimilis populations $(r=0.788, P<0.0001)$. The mean number of two-spotted spider mites recorded on cucumber leaves did not significantly differ between the integrated pest management and control greenhouses $(U=161, P=0.295$; Table 2). In addition, there was no evidence of correlation between the two predatory mite populations $(r=0.010, P=0.949$; Table 3$)$.

\section{Discussion}

This study aimed to assess the efficacy of integrated pest management measures based mainly on biological control that was complemented with chemical sprays only when deemed necessary for the control of whitefly, thrips, and two-spotted spider mite populations in cucumber greenhouse production, as compared to the efficacy of conventional chemical pest control strategies. The growers applied insecticidal and acaricidal sprays at the selected study sites at weekly or 10-day intervals to suppress pest populations and to reduce crop damage. Our study, conducted under the growers' routine production operations at each site, shows that the predatory mites effectively control cucumber pest populations when coupled with additional integrated pest management measures, including but not limited to preventive measures and periodic monitoring. In addition, we show that, depending on the pest and predator species, the integration of biological control agents for cucumber pest management is comparable to, or more effective than, the application of numerous insecticidal and acaricidal sprays throughout a growing season.

As a first step towards meeting this study's objective, we selected appropriate natural enemy organisms to control the region's major cucumber pest populations. The efficacy of $A$. swirskii mites in suppressing whitefly and thrips populations on diverse crops (Messelink et al. 2008; Calvo et al. 2011, 2015) and their origin in the Mediterranean region made this predatory mite suitable for use in our study. Phytoseiulus persimilis was chosen as a predatory mite for two-spotted spider mites because of its reported effectiveness in controlling T. uritcae in diverse crop management systems (McMurtry et al. 2013). Because A. swirskii was reported to prey on $P$. persimilis nymphs, larvae, and eggs, there was concern regarding intraguild predation between the predatory mites. Although intraguild predation may constitute a problem under low prey availability (Haghani et al. 2015; Maleknia et al. 2016), the present study shows that monitoring pest populations and releasing $A$. swirskii mites according to the availability of their preferred food sources, whiteflies and thrips, allowed for the simultaneous introduction of $A$. swirskii and 
P. persimilis. This observation was supported by the absence of a significant correlation between the populations of both predatory mites in the integrated pest management greenhouses at both study sites. This was further supported at site $B$, where towards the end of the growing season, the population of $P$. persimilis increased in the presence of $A$. swirskii.

Temperature and humidity may have diverse effects on both pest and predatory mite population dynamics. The lower temperature threshold of $A$. swirskii development is $11.3{ }^{\circ} \mathrm{C}$, the upper temperature threshold is $37.4{ }^{\circ} \mathrm{C}$, and an optimum development temperature is $31.5^{\circ} \mathrm{C}$ (Lee and Gillespie 2011). Similarly, P. persimilis has optimum development at $27{ }^{\circ} \mathrm{C}$. However, Steneth (1979) showed that $P$. persimilis efficiently controls $T$. urticae at temperatures ranging from $15{ }^{\circ} \mathrm{C}$ to $27{ }^{\circ} \mathrm{C}$. The selected study sites in the present study differed in elevation and latitude, with the average temperature at site A being $2.4{ }^{\circ} \mathrm{C}$ lower than that at site B, whereas the average relative humidity at sites A and B was similar, at 67.3 and $67.5 \%$, respectively. In addition, the present study's experiments were conducted during winter and spring, when mean temperature ranged below the optimum development temperature of both predatory mites $\left(5.8{ }^{\circ} \mathrm{C}\right.$ to $26.2^{\circ} \mathrm{C}$ and $12.18{ }^{\circ} \mathrm{C}$ to $24.3{ }^{\circ} \mathrm{C}$, sites A and $\mathrm{B}$, respectively). Because of this, multiple predatory mite introductions were required to control the pest populations in the integrated pest management greenhouses.

As a second step towards meeting our study objective, we determined the potential of A. swirskii in the simultaneous suppression of whiteflies and thrips on cucumber plants, as compared to the efficacy of chemical pest control. Our data show that, when no whitefly- and thrip-targeting insecticides were used, A. swirskii suppressed whitefly and thrips populations. At both sites (A and B), A. swirskii maintained the whitefly and thrips populations below the economic threshold of 4.6 whiteflies per cucumber leaf (Shen et al. 2005), 1.3 thrips per cucumber leaf (Steiner 1990), and 3-5 thrips per cucumber flower (Shipp et al. 2000), whereas in the control greenhouses, five insecticide sprays targeting whitefly and thrips at site A and 12 such sprays at site B were needed to maintain thrips and whitefly populations below the economic threshold. Our observation agrees with studies reporting the success of biological control agents, including A. swirskii, in controlling greenhouse whitefly populations, as compared to insecticide sprays (Stansly et al. 2004; Rodríguez et al. 2019). Although A. swirskii mites' ability to suppress the whitefly and thrips populations on cucumber plants is well documented (Nomikou et al. 2002, 2003; Messelink et al. 2005, 2006, 2008; Calvo et al. 2011), the efficacy of the mites' pest population suppression had not been compared to widely used conventional chemical pest control strategies.

Likewise, we determined the potential of $P$. persimilis mites for managing two-spotted spider mite populations on cucumber leaves. Our results show that $P$. persimilis mites maintained twospotted spider mite populations below two spider mites per leaf, the population density at the seventh- or eighth-leaf stage at which $23.8 \%$ yield damage is recorded (Atanassov 1997), when use of $P$. persimilis was coupled with three and one acaricidal sprays at sites A and B, respectively. Acaricides were sprayed in the integrated pest management greenhouse due to the delayed arrival of the $P$. persimilis stock and its damage during the shipment. In addition, we report a positive correlation between the populations of $P$. persimilis and the two-spotted spider mites, suggesting the establishment of $P$. persimilis in the integrated pest management greenhouse with two-spotted spider mite serving as a food source. Our data are supported by several studies showing the predation efficiency and oviposition rate of $P$. persimilis when fed a diet consisting of two-spotted spider mites (Masoud 2007; Gillian 2008; Moghadasi et al. 2016; Fathipour et al. 2017; Yanar et al. 2019; Ahmadi et al. 2020). In the control greenhouses at sites A and $\mathrm{B}$, seven and 10 insecticides and acaricides were sprayed, respectively, to control two-spotted spider mite populations. However, in the site A control greenhouse, seven consecutive acaricide sprays failed to keep the two-spotted spider mite population below damaging levels, leading to the premature termination of production in the control greenhouse. Yanar et al. (2019) reported similar results in a screenhouse trial in Tokat province, Turkey, which showed higher control 
of two-spotted spider mite populations on cucumber plants by $P$. persimilis mites compared to conventional acaricide applications.

The present study provides initial insights into the efficacy of simultaneous introductions of two predatory mites to control three major greenhouse cucumber pests in Lebanon, a coastal Mediterranean region. The study also provides an understanding of the benefits of adopting integrated pest management measures compared to those of chemical pest controls. Our results show that $A$. swirskii and $P$. persimilis, when used with additional integrated pest management measures, are highly effective in suppressing whitefly, thrips, and two-spotted spider mite populations on greenhouse cucumbers in Lebanon. Adopting biologically based integrated pest management in the Mediterranean region would yield considerable health benefits to consumers, farmworkers, and the environment by mitigating the negative health hazards of large numbers of pesticide sprays. However, crucial considerations should be highlighted: (1) proper scouting and timing of predatory mite introductions in the greenhouse for efficient pest control are necessary; (2) abiotic factors, including temperature and humidity during the growing season, which might impact predatory mite population dynamics, need to be considered; (3) disease-resistant plant cultivars that reduce pesticide applications and thereby reduce their negative impact on predatory mites should be chosen; and (4) the relatively high cost of international transport of natural enemies as well as damages that may occur during transportation can affect the application of biological control agents. Therefore, local production of natural enemies should be encouraged to eliminate transportation and customs costs and to make biocontrol agents readily available, as needed, to vegetable growers.

Acknowledgements. This work was partially supported by a grant from the Conservation, Food and Health Foundation (CFHF) through a project conducted jointly by the American University of Beirut and the University of Vermont. Partial support was also provided by URB and three private companies, Robinson Agri, Unifert, and Antagro. Co-first authors André Abou-Haidar and Patil Tawidian contributed equally to this study.

Supplementary material. To view supplementary material for this article, please visit https://doi.org/10.4039/tce.2021.15.

\section{References}

Ahmadi, K., Fathipour, Y., and Bashiri, M. 2020. Control of Tetranychus urticae by three predatory mites (Acari: Phytoseiidae) in a commercial greenhouse rose. Journal of Crop Protection, 9: 17-27.

Akoglu, H. 2018. User's guide to correlation coefficients. Turkish Journal of Emergency Medicine, 18: 91-93. https://doi.org/10.1016/j.tjem.2018.08.001.

Atanassov, N. 1997. Effect of the spider mite Tetranychus urticae Koch (Acarina: Tetranychidae) on cucumber yield. Biotechnology \& Biotechnological Equipment, 11: 36-37. https://doi.org/10. 1080/13102818.1997.10818950.

Athias-Henriot, C. 1962. Amblyseius swirskii, un nouveau phytoseiide voisin d'A. andersoni (Acariens Anactinotriches). Annales de l'Ecole Nationale d' Agriculture d' Alger, Algeria, 3: $1-7$.

Barzman, M., Bàrberi, P., Birch, A.N.E., Boonekamp, P., Dachbrodt-Saaydeh, S., Graf, B., et al. 2015. Eight principles of integrated pest management. Agronomy for Sustainable Development, 35: 1199-1215. https://doi.org/10.1007/s13593-015-0327-9.

Calvo, F.J., Bolckmans, K., and Belda, J.E. 2011. Control of Bemisia tabaci and Frankliniella occidentalis in cucumber by Amblyseius swirskii. BioControl, 56: 185-192. https://doi.org/10. 1007/s10526-010-9319-5. 
Calvo, F.J., Knapp, M., van Houten, Y.M., Hoogerbrugge, H., and Belda, J.E. 2015. Amblyseius swirskii: what made this predatory mite such a successful biocontrol agent? Experimental and Applied Acarology, 65: 419-433. https://doi.org/10.1007/s10493-014-9873-0.

Cloyd, R.A. 2016. Western flower thrips (Thysanoptera: Thripidae) and insecticide resistance: an overview and strategies to mitigate insecticide resistance development. Journal of Entomological Science, 51: 257-273. https://doi.org/10.18474/JES16-15.1.

Cock, M.J.W., van Lenteren, J.C., Brodeur, J., Barratt, B.I.P., Bigler, F., Bolckmans, K., et al. 2010. Do new access and benefit sharing procedures under the convention on biological diversity threaten the future of biological control? BioControl, 55: 199-218. https://doi.org/10.1007/ s10526-009-9234-9.

Costa, C.A., Guiné, R.P.F., Costa, D.V.T.A., Correia, H.E., and Nave, A. 2019. Pest control in organic farming. Chapter 3. In Organic farming: global perspectives and methods. Edited by S. Chandran, M.R. Unni, and S. Thomas. Woodhead Publishing, Cambridge, United Kingdom. Pp. 41-90. https://doi.org/10.1016/B978-0-12-813272-2.00003-3.

Demite, P.R., de Moraes, J.G., McMurtry, J.A., Denmark, H.A., and Castilho, R.C. 2015. Phytoseiidae database [online]. Available from www.lea.esalq.usp.br/phytoseiidae [accessed 30 June 2020].

Escudero, L.A. and Ferragut, F. 2005. Life-history of predatory mites Neoseiulus californicus and Phytoseiulus persimilis (Acari: Phytoseiidae) on four spider mite species as prey, with special reference to Tetranychus evansi (Acari: Tetranychidae). Biological Control, 32: 378-384. https://doi.org/10.1016/j.biocontrol.2004.12.010.

Fathipour, Y., Karimi, M., Farazmand, A., and Talebi Ali, A. 2017. Age-specific functional response and predation capacity of Phytoseiulus persimilis (Phytoseiidae) on the two-spotted spider mite. Acarologia, 58: 31-40. https://doi.org/10.24349/acarologia/20184425.

Gao, Y., Lei, Z., and Reitz, S.R. 2012. Western flower thrips resistance to insecticides: detection, mechanisms and management strategies. Pest Management Science, 68: 1111-1121. https://doi. org/10.1002/ps.3305.

Gaum, W.G., Giliomee, J.H., and Pringle, K.L. 1994. Life history and life tables of western flower thrips, Frankliniella occidentalis (Thysanoptera: Thripidae), on English cucumbers. Bulletin of Entomological Research, 84: 219-224. https://doi.org/10.1017/S0007485300039729.

Gillian, F. 2008. Combined use of predatory mites for biological control of Tetranychus urticae (Acari: Tetranychidae) in commercial greenhouse cucumber. International Organisation for Biological and Integrated Control - West Palaeoarctic Regional Section Bulletin, 32: 59-62.

Gontijo, L.M., Margolies, D.C., Nechols, J.R., and Cloyd, R.A. 2010. Plant architecture, prey distribution and predator release strategy interact to affect foraging efficiency of the predatory mite Phytoseiulus persimilis (Acari: Phytoseiidae) on cucumber. Biological Control, 53: 136-141. https://doi.org/10.1016/j.biocontrol.2009.11.007.

Gorman, K., Hewitt, F., Denholm, I., and Devine, G.J. 2002. New developments in insecticide resistance in the glasshouse whitefly (Trialeurodes vaporariorum) and the two-spotted spider mite (Tetranychus urticae) in the UK. Pest Management Science, 58: 123-130. https://doi. org/10.1002/ps.427.

Haghani, S., Golpayegani, A.Z., Saboori, A., and Allahrari, H. 2015. Aggressiveness and predation preference of predatory mites Amblyseius swirskii (Athias-Henriot), Neoseiulus californicus (McGregor) and Phytoseiulus persimilis (Athias-Henriot) (Acari: Phytoseiidae) towards to heterospecific larvae. Ecologica Montenegrina, 3: 46-55.

Hao, X., Shipp, J.L., Wang, K., Papadopoulos, A.P., and Binns, M.R. 2002. Impact of western flower thrips on growth, photosynthesis and productivity of greenhouse cucumber. Scientia Horticulturae, 92: 187-203. https://doi.org/10.1016/S0304-4238(01)00301-6.

Higley, L.G. and Pedigo, L.P. 1996. Economic thresholds for integrated pest management. University of Nebraska Press, Lincoln, Nebraska, United States of America. 
Horowitz, A.R., Ghanim, M., Roditakis, E., Nauen, R., and Ishaaya, I. 2020. Insecticide resistance and its management in Bemisia tabaci species. Journal of Pest Science, 93: 893-910. https://doi. org/10.1007/s10340-020-01210-0.

Hoy, M. 2012. Biology control in agriculture IPM system. Academic Press, New York, New York, United States of America.

Jones, D.R. 2003. Plant viruses transmitted by whiteflies. European Journal of Plant Pathology, 109: 195-219. https://doi.org/10.1023/A:1022846630513.

Kasina, J., Nderitu, J., Nyamasyo, G., Olubayo, F., Waturu, C., Obudho, E., and Yobera, D. 2006. Evaluation of companion crops for thrips (Thysanoptera: Thripidae) management on French bean Phaseolus vulgaris (Fabaceae). International Journal of Tropical Insect Science, 26: 121-125. https://doi.org/10.1079/IJT2006105.

Lebedev, G., Abo-Moch, F., Gafni, G., Ben-Yakir, D., and Ghanim, M. 2013. High-level of resistance to spinosad, emamectin benzoate and carbosulfan in populations of Thrips tabaci collected in Israel. Pest Management Science, 69: 274-277. https://doi.org/10.1002/ps.3385.

Lee, H.S. and Gillespie, D.R. 2011. Life tables and development of Amblyseius swirskii (Acari: Phytoseiidae) at different temperatures. Experimental and Applied Acarology, 53: 17-27. https://doi.org/10.1007/s10493-010-9385-5.

Maleknia, B., Fathipour, Y., and Soufbaf, M. 2016. Intraguild predation among three phytoseiid species, Neoseiulus barkeri, Phytoseiulus persimilis and Amblyseius swirskii. Systematic and Applied Acarology, 21: 417. https://doi.org/10.11158/saa.21.4.4.

Masoud, A. 2007. Study of effectiveness of Phytoseiulus persimilis in control of cucumber twospotted spider mite (Tetranychus urticae complex) in woody and iron greenhouse structures in Varamine region. Pajouhesh and Sazandegi, 19: 96-104.

McClanahan, R.J. 1970. Integrated control of the greenhouse whitefly on cucumbers. Journal of Economic Entomology, 63: 599-601. https://doi.org/10.1093/jee/63.2.599.

McMurtry, J.A., Moraes, G.J.D., and Sourassou, N.F. 2013. Revision of the lifestyles of phytoseiid mites (Acari: Phytoseiidae) and implications for biological control strategies. Systematic and Applied Acarology, 18: 297-320. https://doi.org/10.11158/saa.18.4.1.

Messelink, G.J., Calvo, F.J., Marín, F., and Janssen, D. 2020. Cucurbits. In Integrated pest and disease management in greenhouse crops. Edited by M.L. Gullino, R. Albajes, and P.C. Nicot. Springer International Publishing, New York, New York, United States of America. Pp. 537-566. https://doi.org/10.1007/978-3-030-22304-5_19.

Messelink, G.J., van Maanen, R., van Steenpaal, S.E.F., and Janssen, A. 2008. Biological control of thrips and whiteflies by a shared predator: two pests are better than one. Biological Control, 44: 372-379. https://doi.org/10.1016/j.biocontrol.2007.10.017.

Messelink, G.J., van Steenpaal, S.E.F., and Ramakers, P.M.J. 2006. Evaluation of phytoseiid predators for control of western flower thrips on greenhouse cucumber. BioControl, 51: 753-768. https://doi.org/10.1007/s10526-006-9013-9.

Messelink, G., van Steenpaal, S., and van Wensveen, W. 2005. Typhlodromips swirskii (AthiasHenriot) (Acari: Phytoseiidae): a new predator for thrips control in greenhouse cucumber. International Organisation for Biological and Integrated Control - West Palaeoarctic Regional Section Bulletin, 28: 5.

Moghadasi, M., Allahyari, H., Saboori, A., and Zahedi Golpayegani, A. 2016. Life table and predation capacity of Phytoseiulus persimilis Athias-Henriot (Acari: Phytoseiidae) feeding on Tetranychus urticae Koch (Acari: Tetranychidae) on rose. Journal of Agricultural Science and Technology, 18: 1279-1288.

Mori, H. and Chant, D.A. 1966. The influence of humidity on the activity of Phytoseiulus persimilis Athias-Henriot and its prey Tetranychus urticae (C. L. Koch) (Acarina: Phytoseiidae, Tetranychidae). Canadian Journal of Zoology, 44: 863-871. https://doi.org/10. 1139/z66-087. 
Naranjo, S.E., Ellsworth, P.C., and Frisvold, G.B. 2015. Economic value of biological control in integrated pest management of managed plant systems. Annual Review of Entomology, 60: 621-645. https://doi.org/10.1146/annurev-ento-010814-021005.

Nomikou, M., Janssen, A., and Sabelis, M.W. 2003. Phytoseiid predators of whiteflies feed and reproduce on non-prey food sources. Experimental and Applied Acarology, 31: 15-26. https://doi.org/10.1023/B:APPA.0000005142.31959.e8.

Nomikou, M., Janssen, A., Schraag, R., and Sabelis, M.W. 2001. Phytoseiid predators as potential biological control agents for Bemisia tabaci. Experimental and Applied Acarology, 25: 271-291.

Nomikou, M., Janssen, A., Schraag, R., and Sabelis, M.W. 2002. Phytoseiid predators suppress populations of Bemisia tabaci on cucumber plants with alternative food. Experimental and Applied Acarology, 27: 57-68.

Park, Y.L. and Lee, J.H. 2002. Leaf cell and tissue damage of cucumber caused by two-spotted spider mite (Acari: Tetranychidae). Journal of Economic Entomology, 95: 6.

Park, Y.L. and Lee, J.H. 2005. Impact of two-spotted spider mite (Acari: Tetranychidae) on growth and productivity of glasshouse cucumbers. Journal of Economic Entomology, 98: 7.

Peshin, R. and Dhawan, A.K. (Editors). 2009. Integrated pest management: innovationdevelopment process. Springer Netherlands, Dordrecht, The Netherlands. https://doi.org/10. 1007/978-1-4020-8992-3.

Polis, G.A. 1981. The evolution and dynamics of intraspecific predation. Annual Review of Ecology and Systematics, 12: 225-251. https://doi.org/10.1146/annurev.es.12.110181.001301.

Polis, G.A., Myers, C.A., and Holt, R.D. 1989. The ecology and evolution of intraguild predation: potential competitors that eat each other. Annual Review of Ecology and Systematics, 20: 297-330. https://doi.org/10.1146/annurev.es.20.110189.001501.

Rodríguez, E., Téllez, M.M., and Janssen, D. 2019. Whitefly control strategies against tomato leaf curl New Delhi virus in greenhouse zucchini. International Journal of Environmental Research and Public Health, 16: 2673. https://doi.org/10.3390/ijerph16152673.

Rosenheim, J.A., Welter, S.C., Johnson, M.W., Mau, R.F.L., and Gusukuma-Minuto, L.R. 1990. Direct feeding damage on cucumber by mixed-species infestations of Thrips palmi and Frankliniella occidentalis (Thysanoptera: Thripidae). Journal of Economic Entomology, 83: 1519-1525. https://doi.org/10.1093/jee/83.4.1519.

Shen, B.B., Ren, S.X., Musa, P.H., and Chen, C. 2005. A study on economic threshold of Bemisia tabaci. Acta Agriculturae Universitatis Jiangxiensis, 27: 234-237.

Shipp, J.L., Wang, K., and Binns, M.R. 2000. Economic injury levels for western flower thrips (Thysanoptera: Thripidae) on greenhouse cucumber. Journal of Economic Entomology, 93: 1732-1740. https://doi.org/10.1603/0022-0493-93.6.1732.

Skirvin, D.J. and Fenlon, J.S. 2003. The effect of temperature on the functional response of Phytoseiulus persimilis (Acari: Phytoseiidae). Experimental and Applied Acarology, 31: 37-49. https://doi.org/10.1023/B:APPA.0000005107.97373.87.

Stansly, P.A., Sánchez, P.A., Rodríguez, J.M., Cañizares, F., Nieto, A., Leyva, M.J.L., et al. 2004. Prospects for biological control of Bemisia tabaci (Homoptera, Aleyrodidae) in greenhouse tomatoes of southern Spain. Crop Protection, 23: 701-712. https://doi.org/10.1016/j.cropro. 2003.11.016.

Steiner, M.Y. 1990. Determining population characteristics and sampling procedures for the western flower thrips (Thysanoptera: Thripidae) and the predatory mite Amblyseius cucumeris (Acari: Phytoseiidae) on greenhouse cucumber. Environmental Entomology, 19: 1605-1613. https://doi.org/10.1093/ee/19.5.1605.

Stenseth, C. 1979. Effect of temperature and humidity on the development of Phytoseiulus Persimilis and its ability to regulate populations of Tetranychus urticae [Acarina: Phytoseiidae. Tetranychidae]. Entomophaga, 24: 311-317. https://doi.org/10.1007/BF02374246. 
van Houten, Y.M., Hoogerbrugge, H., and Bolckmans, K.J.F. 2007a. The influence of Amblyseius swirskii on biological control of two-spotted spider mites with the specialist predator Phytoseiulus persimilis (Acari: Phytoseiidae). Integrated control of plant-feeding mites. International Organisation for Biological and Integrated Control - West Palaeoarctic Regional Section Bulletin, 30: 129-132.

van Houten, Y.M., Hoogerbrugge, H., and Bolckmans, K.J. 2007b. Spider mite control by four phytoseiid species with different degrees of polyphagy. International Organisation for Biological and Integrated Control - West Palaeoarctic Regional Section Bulletin, 30: 123-127. van Leeuwen, T., Vontas, J., Tsagkarakou, A., Dermauw, W., and Tirry, L. 2010. Acaricide resistance mechanisms in the two-spotted spider mite Tetranychus urticae and other important Acari: a review. Insect Biochemistry and Molecular Biology, 40: 563-572. https:// doi.org/10.1016/j.ibmb.2010.05.008.

van Lenteren, J.C. 2012. The state of commercial augmentative biological control: plenty of natural enemies, but a frustrating lack of uptake. BioControl, 57: 1-20. https://doi.org/10.1007/s10526011-9395-1.

van Lenteren, J.C. and Woets, J. 1988. Biological and integrated pest control in greenhouses. Annual Review of Entomology, 33: 239-269. https://doi.org/10.1146/annurev.en.33.010188. 001323.

van Maanen, R., Vila, E., Sabelis, M.W., and Janssen, A. 2010. Biological control of broad mites (Polyphagotarsonemus latus) with the generalist predator Amblyseius swirskii. Experimental and Applied Acarology, 52: 29-34. https://doi.org/10.1007/s10493-010-9343-2.

$\mathrm{Xu}, \mathrm{X}$. and Enkegaard, A. 2010. Prey preference of the predatory mite, Amblyseius swirskii between first-instar western flower thrips Frankliniella occidentalis and nymphs of the two-spotted spider mite Tetranychus urticae. Journal of Insect Science, 10: 149. https://doi.org/10.1673/ 031.010.14109.

Yanar, D., Gebologlu, N., Cakar, T., and Engür, M. 2019. The use of predatory mite Phytoseiulus persimilis (Acari: Phytoseiidae) in the control of two-spotted spider mite (Tetranychus urticae Koch, Acari: Tetranychidae) at greenhouse cucumber production in Tokat province, Turkey. Applied Ecology and Environmental Research, 17: 2033-2041. https://doi.org/10.15666/aeer/ 1702_20332041.

Cite this article: Abou-Haidar, A., Tawidian, P., Sobh, H., Skinner, M., Parker, B., and Abou-Jawdah, Y. 2021. Efficacy of Phytoseiulus persimilis and Amblyseius swirskii for integrated pest management for greenhouse cucumbers under Mediterranean environmental conditions. The Canadian Entomologist, 153: 598-615. https://doi.org/10.4039/tce.2021.15. 